\title{
Differences in the Participation of Parents in the Education of Mexican High School Students: Relation with Gender and Level of Studies
}

\author{
Angel Alberto Valdés Cuervo ${ }^{1}$, Teodoro Rafael Wendlandt Amezaga ${ }^{1}$, Ernesto Alonso Carlos Martínez ${ }^{2}$ \& \\ Maricela Urías Murrieta ${ }^{1}$ \\ ${ }^{1}$ Instituto Tecnológico de Sonora, Cd. Obregón, Sonora, México \\ ${ }^{2}$ Instituto Tecnológico Superior de Cajeme, Cd. Obregón, Sonora, México \\ Correspondence: Angel Alberto Valdés Cuervo, Instituto Tecnológico de Sonora, Calle 5 de Febrero, No. 818 Sur, \\ C.P. 85000, Cd. Obregón, Sonora, México. E-mail: angel.valdes@itson.edu.mx
}

Received: March 10, 2014

doi:10.5539/ijps.v6n3p53

\author{
Accepted: June 24, $2014 \quad$ Online Published: July 30, 2014 \\ URL: http://dx.doi.org/10.5539/ijps.v6n3p53
}

\begin{abstract}
The purposes of the study consisted of describing the profiles of subgroups of the parents of high school students based on their participation in the education of their children and establish the relation of these profiles with the gender and level of studies of fathers and mothers. By using a simple random sampling, 374 parents of high school students were selected to participate; of these, 173 (46.2\%) questionnaires were answered by fathers and $201(53.7 \%)$ by mothers. By using a K-means cluster analysis, two subgroups of parents were identified and denominated by their participation as "Low Involvement" $(n=205)$ and "Moderate Involvement" $(n=169)$ respectively, which presented differences in all the types of participation evaluated. However, in both groups a similar profile was identified, which is characterized by a high participation in aspects related to education at home and a low level with regard to aspects concerning school management. Furthermore, a relationship was found between females and higher education, with a greater involvement in the education of children. It is concluded that diverse difficulties exist in families who participate within the school management.
\end{abstract}

Keywords: parents, education, participation, Mexico

\section{Introduction}

Education is seen as a crucial resource for improving the quality of life of people in the economic, social and personal spheres. Its importance has been strengthened by the function ascribed to it within a development based on the opportunities created by knowledge (Foro Consultivo Científico y Tecnológico [FCCyT], 2006; Organisation for Economic Co-operation and Development [OECD], 2007).

In Latin America, governments and civil society have shown signs of recognizing the value of education as a factor that favors the acquisition of skills in people to improve their quality of life and participate in democratic life. Also, since the past half century there has been a gradual expansion of educational coverage at all levels in the region (Bellei, Poblete, Sepúlveda, Orellana, \& Abarca, 2013).

However, despite this momentum that has been given to education within the region, the efforts have not yielded the expected results regarding a decline in the levels of poverty and inequality (Fundación para la Implementación, Diseño, Evaluación y Análisis de Políticas Públicas [IDEA], 2008; Paes de Barros, Ferreira, Molinas \& Saavedra, 2008). The above leads to believe that is not enough to provide educational opportunities to the population, but it is also necessary that these have relevant, efficient and equitable quality to foster and promote social and economic development.

Achieving educational quality is far from being a reality in most Latin American countries and Mexico is not the exception. At all levels of the Mexican educational system difficulties reflected in the quality of education are evident; however, the high school level is perhaps where the problems of educational quality in the country are shown more clearly.

To get an idea, in 2013 only $58 \%$ of young people aged between 15 to 17 who completed middle school, took part in high school education (Instituto Nacional de Evaluación Educativa [INEE], 2013). Moreover, in an 
investigation conducted by the Programme for International Student Assessment (PISA) it was found that Mexican students were placed last among the OECD nations in specific subjects of Math, Science and Reading (Backhoff, 2013).

The results regarding the quality of education have shown that academic achievement is influenced in complex ways by both the characteristics of the students, and by their social, school and family circumstances (Brunner \& Elacqua, 2003; Cornejo \& Redondo, 2007; Murillo \& Román, 2011). In this regard, investigations related to the influence of familial context in school success has shown that aspects such as the socioeconomic status, cultural and social capital, and the involvement of parents in their children's education have significant effects on the students' academic achievement (Bazán, Sánchez, \& Castañeda, 2007; Bourdieu \& Passeron, 2008; Martínez, Bracho, \& Martínez, 2007; Paes de Barros et al., 2008; Schmelkes, 2010; Sheldon \& Epstein, 2005).

The participation of parents in the education of children is precisely the subject of this study. This involves the shared responsibility of teachers and parents to create the conditions that better promote the students' academic success (Bazdresch, 2010; Secretaría de Educación Pública [SEP], 2010). Although this shared responsibility of social factors in education is recognized, the kinds of relationships that are necessary between them has been object of controversies in scientific theories and beliefs of both teachers and parents (Hepworth \& Riojas-Cortez, 2011; Souto-Manning \& Swick, 2006; Wong, 2012).

The importance being given to the involvement of families in achieving quality education is associated, to some extent, to the success shown by the theory of systems in explaining the social phenomena (Bertalanffy, 1976; Luhmann, 1996). Within the specific area of study of family-school relationships, the influence of this theory was reflected in the consolidation of the idea that families and schools should share responsibilities and roles in the education of new generations.

The above confirms that while the school system is partly responsible for the socialization of students, families also have the duty to support the schools in the development of their children's intellectual skills (Epstein, 2011). It was assumed that family involvement in education included all the activities performed in their own homes, within the schools and the community to promote the academic success of their children and all students in general (Graham, 2011; Martiniello, 1999).

In particular, the study was based on the model proposed by Epstein (2011) in which six critical dimensions were identified and whereby the parental involvement in education can be manifested: (a) parenting, includes actions by the family to promote the acquisition of habits, values and behaviors that facilitate adaptation to the school's demands; (b) communication with the school, this refers to practices to maintain and share information with both teachers and administrators in order to promote the child's performance and school's management; (c) support learning at home, includes the supervision and assistance in conducting extracurricular activities that support the learning from school curricula; (d) decision making, includes the participation in organizations that contribute to decisions regarding school and community collaboration; (e) volunteering, implies the involvement in actions to use community resources to support student learning; and (f) collaboration with the community, which involves the actions of the parents to use their communities' resources in order to facilitate the management of the school, and learning of children.

The participation of parents in education helps to improve student learning by allowing them to develop an effective school-family relationship that facilitates mutual understanding, a better understanding of various points of view, the formulation of common goals, a better understanding of the efforts and the role of each of the actors in the educational process (Epstein \& Sheldon, 2006; Newland, Chen, \& Coyl-Shepherd, 2013). This participation has been associated with achieving better learning by students (Bellei, Gubbins, \& López, 2002; Kingston, Huang, Calzada, Dawson-McClure, \& Brotman, 2013) and the decrease of other problems that negatively affect the school environment, such as violence in schools (Coloroso, 2004; Zurita, 2011).

Social participation in education has been considered an important aspect of educational policies aimed at improving the quality of education in Mexico, this since the General Law of Education of 1993, where the Councils of Social Participation were institutionalized. Since then, in the country, there have been actions generated and designed to promote the participation of children's families in education, because it is considered an essential tool in any educational improvement program (Zurita, 2011).

While it is true that in the international arena, especially in the Anglo-Saxon context, there are many research papers published about family involvement in education, the situation is different in Mexico, where it is still an emerging issue in educational research. This statement is based on the review made by Valdés and Vera (2013) regarding the state of knowledge of Mexican research on the subject of "Family, Parenting and School Performance" for the period 2002-2011, which was published by the Mexican Council of Educational Research 
(COMIE, in Spanish). Within this publication only 12 research articles were found that related to the issue of family involvement in the education of children, 11 located at the basic education level and only one for higher education. However, it is interesting to note that there were not any publications found at the high school level, this despite the serious national problems that exist at this level of study.

Considering the importance of families involvement in actions to improve school management and student learning, the few studies about the topic, and as a consequence, the limited existent knowledge about the characteristics of the participation of families in the education at the high school level in Mexico; the present study, based on the Epstein (2011) model, sought to investigate the participation of parents in the education of high school level students within a northwestern state municipality of Mexico, and also determined the relationship of this participation with aspects such as gender, for which it has been reported that mothers are more involved than fathers (Hornby \& Lafaele, 2011; Moreno, Valdés, \& Sánchez, 2008; Valdés, Martín, \& Sánchez, 2009), and the educational level of the parents; where it has been found that a higher level of education is associated with greater and more effective involvement of parents (Flouri \& Buchanan, 2003; Pleck, 1997).

To achieve the purpose of contributing to the knowledge about the forms in which parents of high school students participate in the education of the children, the present study raised the following research questions: (a) Are there subgroups of parents of high school students with significant differences in regards to their participation in the education of children? (b) What are the profiles of parental participation of the identified subgroups? (c) Is there a relationship between gender and the parents' level of studies, with the level of involvement in the education of children?

Based on the abovementioned research questions, this study established the following hypotheses: (a) There are subgroups of parents with different profiles of participation in the education of children, and (b) gender and level of studies are related with the level of involvement of the parents.

\section{Method}

\subsection{Participants}

Ten high schools were intentionally selected in the southern area of the State of Sonora, which counted for a total population of 2,000 students. By using a simple random sampling, based on a probability of $50 \%$ and a confidence level of $95 \%, 374$ students whose parents participated in the study were selected.

The study was answered by 173 (46.2\%) fathers and 201 (53.7\%) mothers, who had a mean age of 48.2 and 44.3 years, respectively; also, it was possible to appreciate that the majority of parents had a high level of studies, meaning had obtained an academic degree or university studies (see Table 1).

Table 1. Distribution of parents with and without higher education

\begin{tabular}{lllll}
\hline & \multicolumn{2}{c}{ Fathers } & \multicolumn{2}{c}{ Mothers } \\
\cline { 2 - 5 } Educational level & $f$ & $\%$ & $f$ & $\%$ \\
\hline Not higher & 52 & 30 & 92 & 45.8 \\
Higher & 121 & 70 & 109 & 54.2 \\
\hline
\end{tabular}

\subsection{Instrument of Evaluation}

\subsubsection{Participation of Parents in the Education of Their Children}

The study adopted the Epstein (2011) model with respect to the six critical dimensions that can be manifested in regards to the participation of parents in their children's education, and from it, a questionnaire of 30-items was designed (five for each form of participation). This questionnaire was answered using a 5-point Likert scale that ranges from 1 (never) to 5 (always).

As mentioned above, six different forms of participation were measured: (a) Parenting (e.g., "I make positive comments regarding my child's teachers"); (b) Communication with the school (e.g., "I talk with teachers or other school personnel about my child's learning"); (c) Support learning at home (e.g., "I provide the proper resources to my child to perform his work at home"); (d) Volunteering (e.g., "I participate as a speaker at conferences or workshops for students"); (e) Decision making (e.g., "I vote in the elections for members of the Parents" Association"); and (f) Collaboration with the community (e.g., "I participate in activities where students can learn by serving the community"). 
To establish the constructive validity of the questionnaire, an exploratory factorial analysis was utilized by the maximum-likelihood method and the Oblimin rotation. The results of the Kaiser-Meyer-Olkin $(\mathrm{KMO}=.80)$ test and Bartlett's test of sphericity showed the adequacy of the factor solution $\left(X^{2}=1020, p=.000\right)$ integrated for the six factors abovementioned in the model, which altogether explained the $61.2 \%$ of the total variance of the scores. The reliability of the instrument was above the normal levels of acceptance with a Cronbach alfa score of .82 .

\subsubsection{Procedure and Data Analysis}

To perform the study, informed consent of school authorities and parents was obtained, this through the voluntary participation by parents ensuring confidentiality of their responses. The surveys were sent to the parents in a sealed envelope, which once answered, was returned to the school by the parents' children in the same manner.

For the analysis of the results the Statistical Package for Social Sciences was used (SPSS, Version 20), along with univariate and multivariate statistics.

\section{Results}

Through a conglomerate analysis (K-means), and based on the level of participation in the education of the children, two subgroups of parents were identified. Regarding the six forms of participation evaluated, both groups showed important differences (see Table 2).

Table 2. Conglomerates obtained from the forms of participation of parents in the education of the children

\begin{tabular}{llll}
\hline & \multicolumn{2}{c}{$\begin{array}{c}\text { First Conglomerate } \\
(n=205)\end{array}$} & $\begin{array}{c}\text { Second Conglomerate } \\
(n=169)\end{array}$ \\
\cline { 2 - 4 } Forms of participation & $M$ & $M$ & $F$ \\
\hline Decision making & 1.49 & 3.00 & $438.4^{*}$ \\
Collaboration with the community & 1.38 & 2.44 & $238.4^{*}$ \\
Communication with the school & 2.97 & 4.10 & $223.5^{*}$ \\
Volunteering & 1.41 & 2.77 & $164.2^{*}$ \\
Support learning at home & 4.10 & 4.57 & $49.4^{*}$ \\
Parenting & 4.13 & 4.47 & $43.4^{*}$ \\
\hline
\end{tabular}

$* p \leq . \overline{05}$.

\subsection{Profiles of Parent Participation in the Conglomerates}

The values of the centroids corresponding to each of the forms of participation allowed to define the first cluster as "Low Involvement" in education; here the parent participation was characterized as weak in almost all respects except in those related to "Parenting" and "Support learning at home", where high scores were obtained.

Parents belonging to the second cluster, defined as "Moderate Involvement" in education, were characterized by an acceptable participation in almost all aspects evaluated, except for those in "Collaboration with the community" and "Volunteering", where their scores were below the mean of the scale.

\subsection{Relationship of Gender and Educational Level of Parents with the Participation in the Education of Children}

Through an $X^{2}$ test it was determined that there is a relationship between the gender of parents and their belonging to a conglomerate, finding that a higher relative proportion of males stood in the subgroup known as Low Involvement in education; while females by contrast, tend to possess a Moderate Involvement (see Table $3)$. 
Table 3. The relationship between the gender of the parent and its conglomerate belonging

\begin{tabular}{llll}
\hline & \multicolumn{2}{c}{ Conglomerates } & \\
\cline { 2 - 3 } Gender & Low Involvement & Moderate Involvement & \\
\cline { 2 - 3 }$X^{2}$ & $f$ & $f$ & $18.78^{*}$ \\
\hline Males & 84 & 89 & \\
Females & 54 & 147 & \\
\hline
\end{tabular}

$* p \leq .05$.

Likewise, the relationship between the educational level -or level of studies- (Not higher: from primary to high school; and Higher: university and above) and its inclusion to a conglomerate was explored. For fathers, no relationship between their educational level and their belonging to any conglomerate was found; however, in the case of mothers, a positive relationship was found between the "higher" educational level and belong to the subgroup identified as of Moderate Involvement (see Table 4).

Table 4. Relationship between the educational level of parents and their conglomerate belonging

\begin{tabular}{|c|c|c|c|c|}
\hline & \multirow[b]{3}{*}{ Educational level } & \multicolumn{2}{|c|}{ Conglomerates } & \multirow[b]{3}{*}{$X^{2}$} \\
\hline & & Low Involvement & Moderate Involvement & \\
\hline & & $f$ & $f$ & \\
\hline \multirow[t]{4}{*}{ Fathers } & Not higher & 27 & 25 & .338 \\
\hline & Higher & 57 & 64 & \\
\hline & & Low Involvement & Moderate Involvement & \\
\hline & & $f$ & $f$ & $X^{2}$ \\
\hline \multirow[t]{2}{*}{ Mothers } & Not higher & 42 & 50 & $30.47 *$ \\
\hline & Higher & 12 & 97 & \\
\hline
\end{tabular}

$* p \leq .05$.

\section{Conclusion}

Regarding the first hypothesis related to identify subgroups of parents based on their involvement in the education of children, the results showed that it is possible to distinguish two conglomerates of parents with differences in the frequency with which they reported to participate in the education of children. The first cluster, which was called Low Involvement, brought together the majority of parents (54.8\%), a result that is consistent with that reported in studies conducted in Mexico, where it indicates that parents participate with a low frequency in aspects related with the education of children (Valdés et al., 2009; Sánchez, Valdés, Reyes, \& Carlos, 2010; Zayas, Corral, \& Lugo, 2011).

Although in the subgroup identified as Moderate Involvement, parents reported greater participation in all the assessed forms in comparison with the Low Involvement subgroup, the pattern of participation in both groups was similar, characterized by a greater participation in the education of the child in aspects related to home (Parenting and Support learning at home) and a low participation in practices related with the processes of the school management (Decision making, Volunteering and Collaboration with the community).

This finding is relevant because it validates those results reported by various authors indicating that one of the weaknesses of the Mexican educational system is the low participation of the various stakeholders (parents and society in general) in the policies and actions aimed to contribute to improving the functioning of educational institutions (Schmelkes, 2010; Zurita, 2011), which is reflected, among other things, in the difficulties for the adequate operation of the Councils of Social Participation throughout the country (Estrada, 2010; Martínez, Bracho, \& Martínez, 2007; Vélez, Linares, Martínez, \& Delgado, 2008).

In addition, the abovementioned should be considered in the policies established to enhance the participation of Mexican families in education, because although it has been reported that the participation that is focused on the 
children's learning has a greater impact on academic performance (Epstein, 2011), those forms of family involvement that impact the operation of the school (or school management) might have a greater result with respect to improving their own educational quality and the quality of the educational system as a whole (Bellei, Gubbins, \& López, 2002; Martiniello, 1999).

It is important to explore whether the pattern of participation found in both subgroups can be associated to those reported in studies conducted in Mexico and Latin America, where it is found that in families the belief persists, that education is essentially a matter for the school and that they should not intervene in matters related to the operation of the same, but only in supporting the child at home (Blanco, Umayahara, \& Reveco, 2004; Valdés \& Urías, 2011).

Another aspect that is worth mentioning in the study, is the finding that a significant proportion of fathers belong to the Low Involvement conglomerate, indicating that they are less involved in the education of children compared with mothers (Hornby \& Lafaele, 2011; Sánchez et al., 2010; Valdés et al., 2009). In addition to the influence of parental gender on the level of participation in education, a greater involvement was demonstrated when the educational level is higher, but only in the case of mothers.

Although the research does not allow us to draw conclusions about the variables that cause low father involvement, with respect to mothers in the education of children, the consistency with which this phenomenon occurs suggests that there are cultural beliefs and practices that allow fathers to play a secondary role with respect to the upbringing and education of children (Gottzén, 2011; Newland et al., 2013).

The importance of the study resides in showing the applicability of the Epstein (2011) model to assess the family involvement in the education in Mexico, as well as the fact of presenting a first approximation of the forms and factors associated to this topic regarding the high school educational level.

This first approximation highlights the necessity to develop actions leading to increasing the involvement of mothers, and especially of fathers, in the education of children. These strategies should be directed to sensitize and empower families to engage more actively and effectively in the education of children, especially with regard to the participation in school management. Finally, this might allow the conversion of social participation in a real element for improving the country's educational system.

\section{References}

Backhoff, E. (2013). México en PISA 2012. Principales resultados [Mexico in PISA 2012. Key results]. México: INEE. Retrieved from http://www.inee.edu.mx/images/stories/2013/principal/PISA2013/version.pdf

Bazán, A., Sánchez, B., \& Castañeda, S. (2007). Relación estructural entre apoyo familiar, nivel educativo de los padres, características del maestro y desempeño en lengua escrita [Structural relationship between family support, educational level of parents, teacher characteristics and performance in written language]. Revista Mexicana de Investigación Educativa, 12(33), 701-729. Retrieved from http://www.redalyc.org/pdf/140/14003312.pdf

Bazdresch, M. (2010). Participación social en educación y política educativa: Una relación en construcción [Social participation in education and educational policy: A relationship in construction]. In B. Barba, \& M. Zorrilla (Eds.), Innovación social en educación: Una base para la elaboración de políticas públicas [Social innovation in education: A base for the elaboration of public policies] (pp. 185-206). México: Universidad Autónoma de Aguascalientes/Siglo XXI.

Bellei, C., Gubbins, V., \& López, V. (2002). Participación de los centros de padres en la educación; Expectativas, Demandas, Desafios y Compromisos [Participation of parents centers in education; Expectations, Demands, Challenges and Commitments]. Santiago de Chile: UNICEF. Retrieved from http://www.unicef.cl/archivos_documento/30/Centro_Padres1.pdf

Bellei, C., Poblete, X., Sepúlveda, P., Orellana, V., \& Abarca, G. (2013). Situación educativa de América Latina y el Caribe: Hacia la educación de calidad para todos al 2015 [Educational situation of Latin America and the Caribbean: Towards quality education for all by 2015]. Santiago de Chile: UNESCO. Retrieved from http://www.unesco.org/new/fileadmin/MULTIMEDIA/FIELD/Santiago/images/SITIED-espanol.pdf

Bertalanffy, L. (1976). Teoría general de los sistemas: Fundamentos, desarrollo, aplicaciones [General Systems Theory: Foundations, Development, Applications]. México: Fondo de Cultura Económica.

Blanco, R., Umayahara, M., \& Reveco, O. (2004). Participación de las familias en la educación infantil Latinoamericana [Participation of families in Latin American childhood education]. Santiago de Chile: UNESCO. Retrieved from http://unesdoc.unesco.org/images/0013/001390/139030s.pdf 
Bourdieu, P., \& Passeron, J. (2008). los herederos; los estudiantes y la cultura [the heirs; the students and culture]. México: Siglo XXI.

Brunner, J., \& Elacqua, G. (2003). Informe capital humano en Chile [Human capital in Chile Report]. Chile: Universidad Adolfo Ibáñez. Retrieved from http://www.oei.es/etp/informe_capital_ humano_chile_brunner.pdf

Coloroso, B. (2004). The bully, the bullied and the bystander. United States: Harper Collins.

Cornejo, R., \& Redondo, J. (2007). Variables y factores asociados al aprendizaje escolar. Una discusión desde la investigación actual [Variables and factors associated to school learning. A discussion from current research]. Estudios Pedagógicos, 33(2), 155-175. http://dx.doi.org/10.4067/S0718-07052007000200009

Epstein, J. (2011). School, family, and community partnerships: Preparing educators and improving schools (2nd ed.). Philadelphia, PA: Westview Press.

Epstein, J., \& Sheldon, S. (2006). Moving Forward: Ideas for Research on School, Family, and Community Partnerships. In C. Clifton, \& S. Ronald (Eds.), The Sage Handbook for Research in Education: Engaging ideas and enriching inquiry (pp. 115-150). Thousand Oaks, Calif.: Sage Publications. http://dx.doi.org/10.4135/9781412976039

Estrada, M. (2010). Jóvenes y participación social en la educación. Una experiencia en el nivel medio superior de Chiapas, México [Youth and social participation in education. An experience in the middle upper level in Chiapas, Mexico]. Revista Iberoamericana sobre Calidad, Eficacia y Cambio en Educación, 8(3), 149-166. Retrieved from http:www.redalyc.org/articulo.oa?id=55115052010

Flouri, E., \& Buchanan, A. (2003). What predicts fathers' involvement with their children? A prospective study of intact families. British Journal of Developmental Psychology, 21(1), 81-97. http://dx.doi.org/10.1348/026151003321164636

Foro Consultivo Científico y Tecnológico. (2006). Diagnóstico de la política científica, tecnológica y de fomento a la innovación en México (2000-2006) [Diagnosis of scientific, technological and fostering innovation policies in Mexico 2000-2006]. México: FCCyT. Retrieved from http://www.foroconsultivo.org.mx/libros_editados/diagnostico.pdf

Fundación para la Implementación, Diseño, Evaluación y Análisis de Políticas Públicas. (2008). La educación básica en México: clasificación estatal y recomendaciones [The basic education in Mexico: states classification and recommendations]. México: IDEA.

Gottzén, L. (2011). Involved fatherhood? Exploring the educational work of middle-class men. Gender and Education, 23(5), 619-634. http://dx.doi.org/10.1080/09540253.2010.527829

Graham, D. (2011). Family-school partnerships: Towards sustainable pedagogical practice. Asia-Pacific Journal of Teacher Education, 39(2), 165-176. http://dx.doi.org/10.1080/1359866X.2011.560651

Hepworth, E., \& Riojas-Cortez, M. (2011). Parents as Partners in Education: Families and Schools Working Together (8th ed.). United States: Pearson.

Hornby, G., \& Lafaele, R. (2011). Barriers to parental involvement in education: An explanatory model. Educational Review, 63(1), 37-52. http://dx.doi.org/10.1080/00131911.2010.488049

Instituto Nacional de Evaluación Educativa. (2013). Panorama Educativo de México 2012. Indicadores del Sistema Educativo Nacional. Educación Básica y Media Superior [Educational Panorama of Mexico 2012. Indicators of the National Education System. Basic and Middle Higher Education]. México: INEE. Retrieved from http://www.inee.edu.mx/images/stories/2013/publicaciones/Panorama2012 /Panorama2012260613.pdf

Kingston, S., Huang, K., Calzada, E., Dawson-McClure, S., \& Brotman, L. (2013). Parent involvement in education as a moderator of family and neighborhood socioeconomic context on school readiness among young children. Journal of Community Psychology, 41(3), 265-276. http://dx.doi.org/ 10.1002/jcop.21528

Luhmann, N. (1996). Introducción a la teoría de sistemas [Introduction to systems theory]. México: Instituto Tecnológico y de Estudios Superiores de Occidente.

Martínez, A., Bracho, T., \& Martínez, C. (2007). Los Consejos de Participación Social en la Educación y el Programa Escuelas de Calidad: ¿Mecanismos Sociales para la Rendición de Cuentas? [The Councils of Social Participation in Education and the Quality Schools Program: Social Mechanisms for Accountability?] 
México: Programa Interinstitucional de Investigación-Acción sobre Democracia, Sociedad Civil y Derechos Humanos.

Martiniello, M. (1999). Participación de los Padres en la Educación: Hacia una Taxonomía para América Latina [Participation of Parents in Education: Toward a Taxonomy for Latin America]. Development Discussion Paper No. 709, Central America Project Series. Harvard Institute for International Development. Retrieved from http://www.cid.harvard.edu/hiid/709.pdf

Moreno, E., Valdés, A., \& Sánchez, P. (2008). Participación de los padres en la educación de estudiantes de secundarias [Parental involvement in the education of middle school students]. Educando para el nuevo milenio, 15(16), 168-171. Retrieved from http://www.revistaeducando.files.wordpress.com/2010/10 /revista_educando_itson_16-2008.pdf

Murillo, F., \& Román, M. (2011). La escuela o la cuna? Evidencias sobre su aportación al rendimiento de los estudiantes de América Latina. Estudio multinivel sobre la estimación de los efectos escolares [Does the school or crib? Evidence of their contribution to the students' performance in Latin America. Multilevel study on the estimation of school effects]. Revista de Currículum y Formación de Profesorado, 15(3), 27-50. Retrieved from http://www.redalyc.org/pdf/567/56722230003.pdf

Newland, L., Chen, H., \& Coyl-Shepherd, D. (2013). Associations Among Father Beliefs, Perceptions, Life Context, Involvement, Child Attachment and School Outcomes in the U.S. and Taiwan. Fathering: A Journal of Theory, Research, and Practice about Men as Fathers, 11(1), 3-30. http://dx.doi.org/10.3149/fth.1101.3

Organisation for Economic Co-operation and Development. (2007). Higher Education and Regions: Globally Competitive, Locally Engaged. Paris, France: OECD. Retrieved from http://www.oecd.org/edu/imhe/highereducationandregionsgloballycompetitivelocallyengaged.htm

Paes de Barros, R., Ferreira, F., Molinas, J., \& Saavedra, J. (2008). Measuring Inequality of Opportunities in Latin America and the Caribbean. Washington, DC: World Bank. Retrieved from http://siteresources.worldbank.org/LACEXT/Resources/258553-1222276310889/Book_HOI.pdf

Pleck, J. (1997). Paternal involvement: Levels, sources, and consequences. In L. Michael (Ed.), The role of the father in child development (pp. 66-103). Hoboken, NJ: John Wiley and Sons, Inc.

Sánchez, P., Valdés, A., Reyes, N., \& Carlos, E. (2010). Participación de padres de estudiantes de educación primaria en la educación de sus hijos en México [Participation of parents of students of primary education in the education of their children in Mexico]. Revista Liberabit, 16(1), 71-80. Retrieved from http://www.scielo.org.pe/pdf/liber/v16n1/a08v16n1.pdf

Secretaría de Educación Pública. (2010). Programa escuelas de calidad. Orientaciones para activar la participación social en las escuelas de educación básica [Quality schools program. Guidelines to activate the social participation in basic education schools]. México: SEP.

Sheldon, S., \& Epstein, J. (2005). Involvement Counts: Family and Community Partnerships and Mathematics Achievement. The Journal of Educational Research, 98(4), 196-206. Retrieved from http://www.jstor.org/stable/27548080

Schmelkes, S. (2010). El papel de la comunidad en el cambio desde la escuela [The role of the community in the change from school]. In B. Barba, \& M. Zorrilla (Eds.), Innovación social en educación: Una base para la elaboración de politicas públicas [Social innovation in education: A base for the elaboration of public policies] (pp. 207-223). México: Universidad Autónoma de Aguascalientes/Siglo XXI.

Souto-Manning, M., \& Swick, K. (2006). Teachers' Beliefs about Parent and Family Involvement: Rethinking our Family Involvement Paradigm. Early Childhood Education Journal, 34(2), 187-193. http://dx.doi.org/10.1007/s10643-006-0063-5

Valdés, A., Martín, M., \& Sánchez, P. (2009). Participación de los padres de alumnos de educación primaria en las actividades académicas de sus hijos [Parental participation of primary education students in their children's academic activities]. Revista Electrónica de investigación Educativa, 11(1), 1-17. Retrieved from http://www.redalyc.org/pdf/155/15511137012.pdf

Valdés, A., \& Vera, J. (2013). Familia y desarrollo. Textos, contextos y pretextos [Family and development. Texts, contexts and pretexts]. In M. de Agüero (Ed.), Aprendizaje y desarrollo 2002-2011 [Learning and development 2002-2011] (pp. 217-275). México, DF: ANUIES/COMIE. 
Valdés, A., \& Urías, M. (2011). Creencias de padres y madres acerca de la participación en la educación de sus hijos [Beliefs of parents regarding the participation in their children's education]. Perfiles Educativos, 33(134), 99-114. Retrieved from http://www.journals.unam.mx/index.php /perfiles/article/viewFile/27943/25850

Vélez, H., Linares, M., Martínez, A., \& Delgado, M. (2008). Participación social en escuelas preescolares y primarias. Reflexiones y propuestas desde las experiencias de una organización social [Social participation in preschool and primary schools. Reflections and proposals from the experiences of a social organization]. Distrito Federal, México: Hacia una Cultura Democrática A.C.

Wong, P. (2012). Parents' perspectives of the home-school interrelationship: A study of two Hong Kong-Australian families. Australasian Journal of Early Childhood, 37(4), 59-67. Retrieved from $\mathrm{http}: / /$ search.informit.com.au/documentSummary; $\mathrm{dn}=062013084362165$;res=IELHSS

Zayas, F., Corral, F., \& Lugo, D. (2011). El involucramiento de padres y madres de familia en la educación superior [The involvement of fathers and mothers in higher education]. Paper presented at the XI Congreso Nacional de Investigación Educativa, Distrito Federal, México, COMIE. Retrieved from http://www.comie.org.mx/congreso/memoriaelectronica/v11/docs/area_16/0417.pdf

Zurita, Ú. (2011). Los desafíos del derecho a la educación en México a propósito de la participación social y la violencia escolar [The challenges of the right to education in Mexico with regard to social participation and school violence]. Revista Mexicana de Investigación Educativa, 16(48), 131-158. Retrieved from http://www.scielo.org.mx/pdf/rmie/v16n48/v16n48a7.pdf

\section{Copyrights}

Copyright for this article is retained by the author(s), with first publication rights granted to the journal.

This is an open-access article distributed under the terms and conditions of the Creative Commons Attribution license (http://creativecommons.org/licenses/by/3.0/). 